\title{
Expression of AIF, PARP, and miRNAs MIR-145, MIR-210, and MIR-486 Associated with Apoptosis in the Corpus Cavernosum of Rats Subjected to Chronic Alcoholism Model
}

\author{
Expresión de AIF, PARP y miRNAs MIR-145, MIR-210 y MIR-486 Asociados con Apoptosis \\ en el Cuerpo Cavernoso de Ratas Sometidas a Modelo de Alcoholismo Crónico
}

Vagner Schiavoni Sarraipo $^{1}$; Fermino Sanches Lizarte Neto ${ }^{1}$; Camila Albuquerque Mello de Carvalho ${ }^{1}$; Jairo Pinheiro da Silva ${ }^{1}$; Marina Toledo Durand²; Bruno Cezar Schimming ${ }^{3}$; Marcelo Martinez ${ }^{4}$; Maria de Fátima Tazima Sorita Galli'; Fabianna de Oliveira Buono ${ }^{1}$; Maria Fernanda Barbirato da Mata Tiezzi ${ }^{1}$; Paulo Cezar Novais ${ }^{1,5}$; Isabella Stracieri Gula ${ }^{1}$; José Antônio

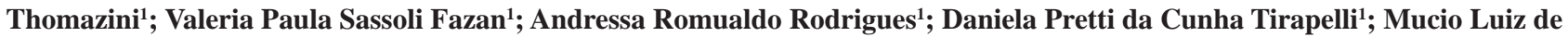
Assis Cirino' ${ }^{1}$, Carlos Augusto Fernandes Molina ${ }^{1}$; Silvio Tucci Junior ${ }^{1}$ \& Luis Fernando Tirapelli ${ }^{1}$

SARRAIPO, V. S.; NETO, F. S. L.; CARVALHO, C. A. M.; SILVA, J. P.; DURAND, M. T.; SCHIMMING, B. C.; MARTINEZ, M.; GALLI, M. F. T. S.; BUONO, F. O.; TIEZZI, M. F. B. M.; NOVAIS, P. C.; GULA, I. S.; THOMAZINI, J. A.; FAZAN, V. P. S.; RODRIGUES, A. R.; TIRAPELLI, D. P. C.; CIRINO, M. L. A.; MOLINA, C. A. F.; JUNIOR, S. T. \& TIRAPELLI, L. F. Expression of AIF, PARP, and miRNAs MIR-145, MIR-210, and MIR-486 associated with apoptosis in the corpus cavernosum of rats subjected to chronic alcoholism model. Int. J. Morphol., 38(6):1639-1644, 2020.

SUMMARY: Previous studies from our group described the consequences of using ethanol on penile erection. Nevertheless, the molecular mechanisms surrounding microRNAs, apoptosis process and their relationship with erectile dysfunction associated with alcohol consumption are still poorly understood. The objective of this analysis was to evaluate the mechanism of apoptosis by the expression of AIF and PARP, as well as their regulatory microRNAs: miR-145, miR-210 and miR-486, in the corpus cavernosum of rats submitted to a semivoluntary alcoholism model. For this study 24 Wistar rats were divided into two groups: control (C) and treated with $20 \%$ ethanol (A) for seven weeks. The corpus cavernosum samples were prepared for immunohistochemical analysis of AIF and PARP protein expression, and microRNAs miR-145, miR-210, miR-486 gene expression in cavernous tissue was performed by real time PCR. The immunohistochemical analysis showed little nuclear positive labeling for the protein PARP and AIF in the corpus cavernosum of control and ethanol treated animals. After analysis of miR-145, -210 and -486 microRNA expression in the 12 animals studied, no results were found with significant statistical difference between the control and alcoholized groups. The expression of AIF and PARP and their regulatory microRNAs involved in apoptotic process (miR-145, miR-210 and miR-486) were not altered in the corpus cavernosum of rats submitted to semivoluntary alcoholism.

KEY WORDS: Alcoholism; Apoptosis; Erectile Dysfunction; MicroRNAs.

\section{INTRODUCTION}

Penile erection is a neurovascular phenomenon which requires dilation of the penile vasculature, relaxation of smooth muscle, increased intracavernous blood flow and normal veno-occlusive function (Drake et al., 2015). According to the National Institute of Health and the American Urological Association, the inability to achieve or maintain the proper penile erection for sexual satisfaction is called erectile dysfunction (ED). Basically, the main diagnostic tool for ED is medical and sexual history. Rarely, complementary tests are needed (Glina et al., 2014).

Since penile erection is dependent on competent vascularization, substances that are known to damage vessels and their functions can affect it. For example, excessive alcohol consumption. Chronic and excessive alcohol consumption has a cytotoxic effect that harms health in its

\footnotetext{
1 Department of Surgery and Anatomy, Medical School of Ribeirão Preto - São Paulo Univesity - USP, Brazil.

2 Department of Medicine, University of Ribeirão Preto, Brazil.

3 Department of Anatomy, Biosciences Institute of Botucatu, UNESP, Botucatu, SP, Brazil.

4 Department of Morphology and pathology, UFSCAR, São Carlos, SP, Brazil.

5 Department of odontology and Postgraduate Program in Structural and Functional Interactions in Rehabilitation, UNIMAR, Marilia, SP, Brazil.
} 
SARRAIPO, V. S.; NETO, F. S. L.; CARVALHO, C. A. M.; SILVA, J. P.; DURAND, M. T.; SCHIMMING, B. C.; MARTINEZ, M.; GALLI, M. F. T. S.; BUONO, F. O.; TIEZZI, M. F. B. M.; NOVAIS, P. C.; GULA, I. S.; THOMAZINI, J. A.; FAZAN, V. P. S.; RODRIGUES, A. R.; TIRAPELLI, D. P. C.; CIRINO, M. L. A.; MOLINA, C. A. F.; JUNIOR, S. T. \& TIRAPELLI, L. F. Expression of AIF, PARP, and miRNAs MIR-145, MIR-210, and MIR-486 associated with apoptosis in the corpus cavernosum of rats subjected to chronic alcoholism model. Int. J. Morphol., 38(6):1639-1644, 2020.

entirety, especially in events that are dependent on the integrity of vascularization such as penile erection (O'Keefe et al., 2014).

Previous studies from our group described the consequences of using ethanol on penile erection. Mice submitted to a semivoluntary chronic alcoholism model had lower serum testosterone rate, increased corpus cavernosum contraction from noradrenergic stimulation and decreased endothelial relaxation induced by acetylcholine. However, the nitrate rate, which is a way of estimating NO, was unchanged in the alcoholic group compared to the control group (Cheng et al., 2007).

The effects of alcohol abuse are widely studied in relation to erection disorders. On the other hand, it is necessary to understand the molecular mechanisms that promote these disorders which are usually related to microRNAs. MicroRNAs are small molecules known to be associated with various cellular processes, such as cell differentiation, proliferation, apoptosis and cell metabolism. The current literature shows us that about $60 \%$ of human genes are controlled by microRNAs, and there are several studies showing that a single microRNA can regulate hundreds of different target genes, which determines a great impact on the numerous physiological and pathological processes (Lizarte et al., 2010).

One of the many cellular processes associated with microRNAs is apoptosis. This process is regulated by genes and involves the coordinated and efficient action of several enzymatic activity groups of proteins, known as caspases9, or can be driven by caspases independent pathways by means of the action of a flavoprotein, called Apoptosis-Inducing Factor (AIF), or by the action of enzymes of the poly (ADPribose) polymerase (PARP) family (Kulshreshtha et al., 2007; Lizarte et al., 2009).

In addition to apoptosis, recent studies have revealed that microRNAs can also regulate nitric oxide expression, endothelial cell proliferation and migration, smooth muscle function, and androgen-dependent erection (Burgos-Aceves et al., 2018). Besides, Gonçalves et al. (2018) studied the expression of microRNAs-155 and -199 and their association with endothelin receptors (ETa and ETb) in corpus cavernosum of alcoholic rats, and observed that these receptors were regulated by these microRNAs.

Although different levels of microRNA expression have been identified in various types of animal and human models with ED, their role in the context of benign urological disease remains limited (Waltereit \& Weller, 2002; da Cunha et al., 2017) and further studies are needed in order to reveal direct evidence of the regulatory mechanisms of microRNAs in the mechanism of ED.

Although most evidence in the literature shows data correlating the expression of microRNAs to the process of ethyl dependence and liver damage 19 , we sought to evaluate from an experimental model of chronic alcoholism the mechanism of apoptosis in the corpus cavernosum by studying protein expression and some microRNAs, which may be associated with ED. Therefore, the aim of this study is to evaluate the mechanism of apoptosis by the expression of AIF and PARP, as well as their regulatory microRNAs: miR-145, miR-210 and miR-486, in the corpus cavernosum of rats subjected to semivoluntary alcoholism model.

\section{MATERIAL AND METHOD}

A total of 24 male Wistar rats (Rattus norvegicus) from the University of São Paulo's Ribeirão Preto Campus, after approval by the Ethics Committee of our institution, were used. They were divided into 2 groups and followed by 4 weeks after the adaptive period: control group (C), alcoholic group (A), all groups consisting of 12 animals each.

For the animals in the ethanol group (A), the model of "semi-voluntary alcoholism" was used, in which the ethanol solution at $20 \%$ was the only liquid available to these animals, following a model proposed by Tirapelli et al. 2008, where there was an adaptive phase that consisted of increasing the ethanol supply concentrations weekly from $5,10,20 \%$, starting the experimental phase after the third week of treatment. The rats of all groups were followed for 7 weeks and then killed humanely.

For the immunohistochemistry, the corpus cavernosum of control $(n=6)$, alcoholic $(n=6)$ were immediately removed and fixed for $24 \mathrm{~h}$ in ice-cold $0.1 \mathrm{~mol} /$ 1 PBS (pH 7.4), containing $4 \%$ paraformaldehyde, followed by cryoprotection in $15 \%$ of sucrose for $4 \mathrm{~h}$ and $30 \%$ sucrose overnight at $4{ }^{\circ} \mathrm{C}$. Longitudinal sections $(10 \mu \mathrm{m})$ of the corpus cavernosum were immunohistochemically analyzed via avidin-biotin-peroxidase (Novostain Super ABC Kit - Universal, NCL-ABCu, Novocastra Laboratories Ltd, Newcastle upon Tyne, UK) - (universal Kit mach 4 BIOCARE). The longitudinal sections were incubated with $3 \% \mathrm{H} 2 \mathrm{O} 2$, followed by antigen retrieval with a moist heat steam cooker Optistream Plus (Krups North America, Inc., Millville, New Jersey, USA) with $10 \mathrm{mM}$ citrate buffer at $\mathrm{pH} 6.0$ for 35 minutes. Then, the sections were incubated for 24 hours in a primary antibody: AIF and PARP diluted 1/300 in PBS solution of bovine serum albumin (BSA). Subsequently, the 
SARRAIPO, V. S.; NETO, F. S. L.; CARVALHO, C. A. M.; SILVA, J. P.; DURAND, M. T.; SCHIMMING, B. C.; MARTINEZ, M.; GALLI, M. F. T. S.; BUONO, F. O.; TIEZZI, M. F. B. M.; NOVAIS, P. C.; GULA, I. S.; THOMAZINI, J. A.; FAZAN, V. P. S.; RODRIGUES, A. R.; TIRAPELLI, D. P. C.; CIRINO, M. L. A.; MOLINA, C. A. F.; JUNIOR, S. T. \& TIRAPELLI, L. F. Expression of AIF, PARP, and miRNAs MIR-145, MIR-210, and MIR-486 associated with apoptosis in the corpus cavernosum of rats subjected to chronic alcoholism model. Int. J. Morphol., 38(6):1639-1644, 2020.

blocking of the endogenous biotin was performed (Biotin Blocking System, Dako North America, Inc., Carpinteria, USA) and only then the sections were incubated with secondary antibody HRP kit MACH 4-Universal Polymer (M4BD534, Biocare Medical) and then with avidin-biotinperoxidase kit same (1/200 in PBS). Color was developed by the addition of diaminobenzidine (Sigma Chemical, St. Louis, USA).

The sections were dehydrated in ethanol, cleared with xylene and mounted under the cover slip with Permount liquid (Fisher Scientific Company LLC, Fair Lawn, New Jersey, USA).

To evaluate the background reaction, the procedures were also performed in sections incubated only with the secondary antibodies (indirect technique) or in the absence of antibodies (direct technique). The slides for immunohistochemistry were analyzed using the Zeiss microscope Axioskop 2 plus model in magnification of 400 times. The number of cells with positive staining for AIF and PARP was measured by using a camera (Axio Cam, Zeiss, Germany) and the program Axiovision 4.6 (Zeiss, Germany).

Analysis of expression profile of the miRNAs-145, 210 and 486. The expression profile of the miRNAs-145, 210 and 486 were analyzed in the cavernous tissue samples from each animal. Total cellular RNA was extracted using Trizol Reagent (Invitrogen, Carlsbad, CA) and RNA was reverse transcribed to single-stranded cDNA, using a High Capacity Kit (Applied Biosystems, Foster City, CA) according to the manufacturer's protocol. For quantitative analysis of the miRNAs-145, 210 and 486, we used the commercially available system TaqMan Assay-ondemand (Applied Biosystems). Reverse transcription was performed using $5 \mathrm{ng}$ total RNA for each sample in $7,5 \mu \mathrm{L}$ of the total reaction mixture. The cDNA obtained was diluted 1:4 and $4.5 \mu \mathrm{L}$ was used for each $10 \mu \mathrm{L}$ of the quantitative real-time polymerase chain reaction mixture using the TaqMan Master Mix (Applied Biosystems). All reactions were carried out in duplicate and analyzed with the 7500 Sequence Detection System apparatus (Applied Biosystems). Data were analyzed using the ABI-7500 SDS software. The total RNA absorbed was normalized on the basis of the Ct value for U6 (000391). The variation in expression among samples was calculated by the $2-\Delta \Delta \mathrm{Ct}$ method, with the mean $\Delta \mathrm{Ct}$ value for a group of 6 samples from control rats being used as a calibrator.

Statistical analysis. For the evaluation of all studies in this research (protein expression and gene expression), statistical analysis was performed using the $\mathrm{t}$ test and Mann Whitney post-test. We used the GraphPad Prism program 6:00 version for Windows (GraphPad Software, San Diego - California USA) and considered statistically significant $p$ values $<0,05$.

\section{RESULTS}

Immunohistochemical analysis. Positive markings for PARP and AIF were similar in both groups evaluated without statistically significant difference (Figs. 1 and 2).

\section{PARP}

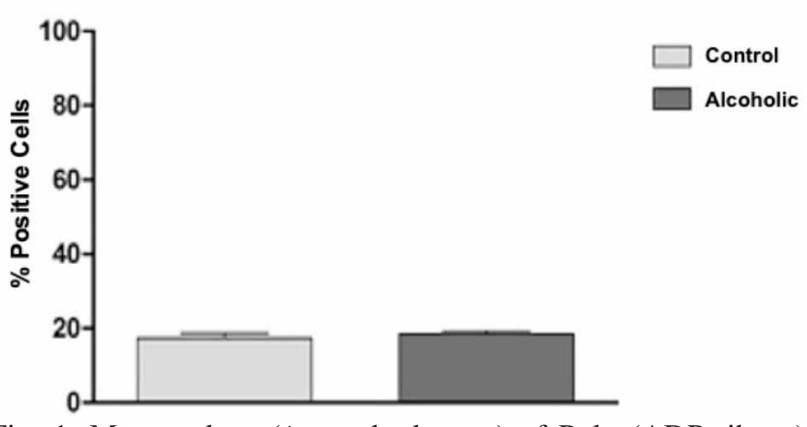

Fig. 1. Mean values ( \pm standard error) of Poly (ADP-ribose) polymerase (PARP-1) protein expression in the control and alcoholic animals. There was no statistical difference in the comparison between the groups ( $\mathrm{p}=0.6279$, Mann-Whitney).

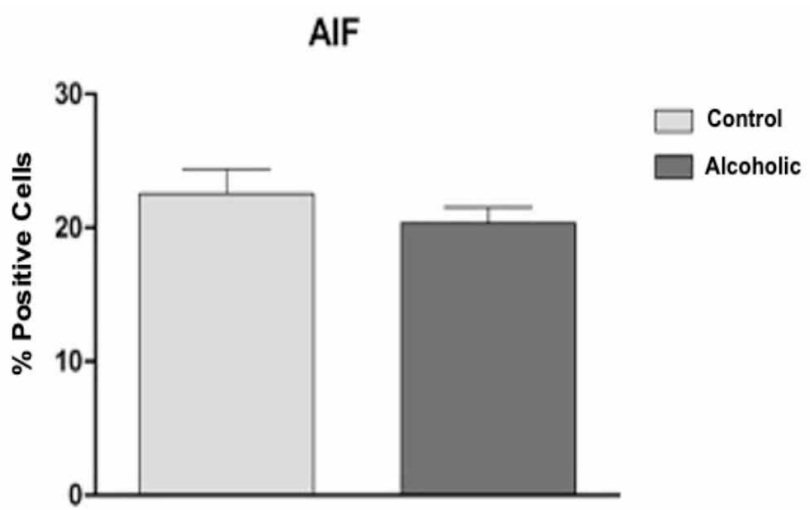

Fig. 2. Mean values ( \pm standard error) of Apoptosis-Inducing Factor (AIF) protein expression in control and alcoholic animals. There was no statistical difference between groups $(\mathrm{p}=0.6831$, MannWhitney).

They were diffuse in the cavernous tissue, homogeneous and similar when comparing their distribution in connective tissue (between the cavernous spaces), smooth muscle cells and endothelial cells lining the cavernous spaces (Fig. 3).

Real Time PCR After analysis of miR-145, -210 and 486 microRNA expression, no significant differences were found between the control and alcoholic groups (Figs. 4 to 6). 

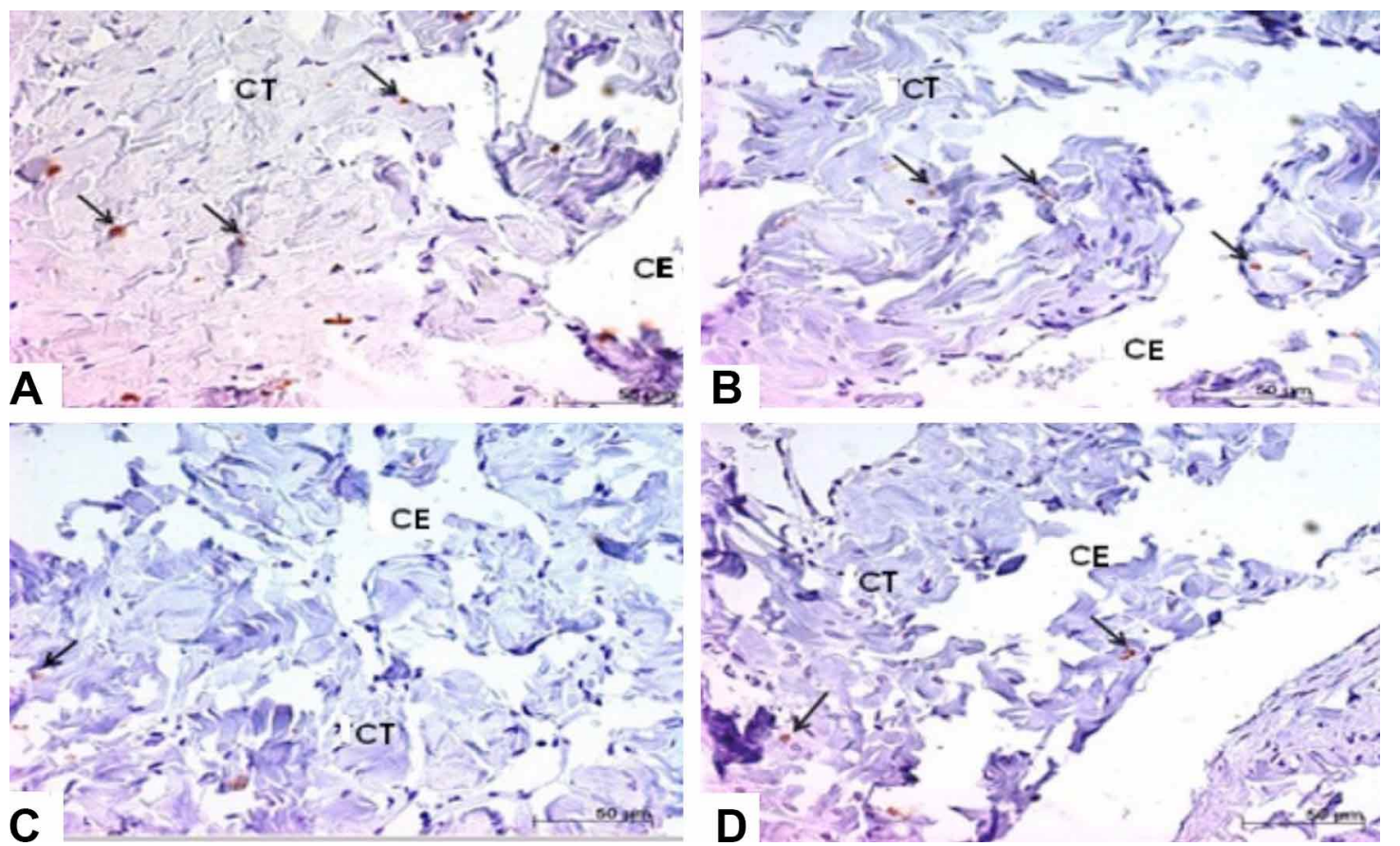

Fig. 3. Photomicrographs of the cavernous bodies of rats showing the immunohistochemical marking for PARP-1 (in A: control group and B: ethanol group) and AIF (in C: control group and D: ethanol group). Arrows indicate some cells with nuclear positive labeling. Cavernous spaces (CE); connective tissue (CT). 400x

$\operatorname{miR}-145$

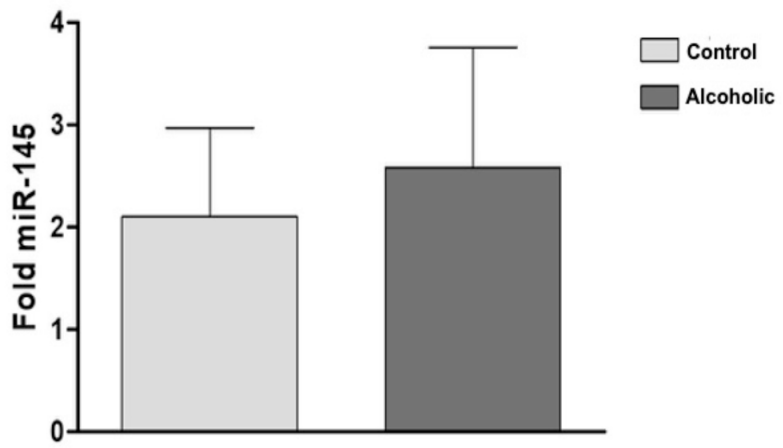

Fig. 4. Mean values ( \pm standard error) of microRNA-145 expression from control and alcoholic animals. There was no statistically significant difference between groups ( $\mathrm{p}=0.9372$, Mann-Whitney).

$\operatorname{miR}-210$
$\operatorname{miR}-210$

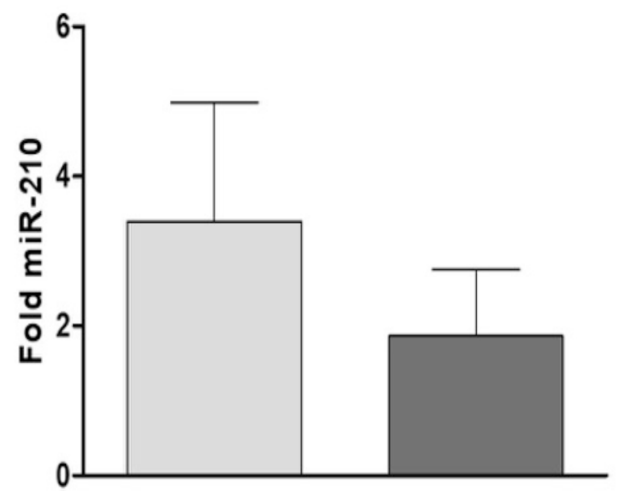

Fig. 6. Mean values ( \pm standard error) of microRNA-486 expression from control and alcoholic animals. There was no statistically significant difference between groups $(\mathrm{p}=0.9372$, Mann-Whitney.

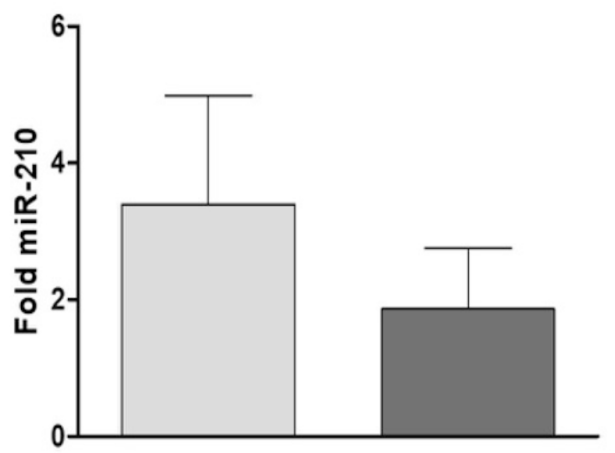

Control

Alcoholic

Fig. 5. Mean values ( \pm standard error) of microRNA-210 expression from control and alcoholic animals. There was no statistically significant difference between the groups ( $\mathrm{p}=0.3939$, Mann-Whitney). 
SARRAIPO, V. S.; NETO, F. S. L.; CARVALHO, C. A. M.; SILVA, J. P.; DURAND, M. T.; SCHIMMING, B. C.; MARTINEZ, M.; GALLI, M. F. T. S.; BUONO, F. O.; TIEZZI, M. F. B. M.; NOVAIS, P. C.; GULA, I. S.; THOMAZINI, J. A.; FAZAN, V. P. S.; RODRIGUES, A. R.; TIRAPELLI, D. P. C.; CIRINO, M. L. A.; MOLINA, C. A. F.; JUNIOR, S. T. \& TIRAPELLI, L. F. Expression of AIF, PARP, and miRNAs MIR-145, MIR-210, and MIR-486 associated with apoptosis in the corpus cavernosum of rats subjected to chronic alcoholism model. Int. J. Morphol., 38(6):1639-1644, 2020.

\section{DISCUSSION}

Several factors such as systemic arterial hypertension, diabetes mellitus, smoking and alcoholism can negatively affect the physiological mechanism of penile erection, consequently leading to ED. Despite the fact that there is a strong association between alcohol consumption and increased incidence of ED, the molecular mechanisms mediated by microRNAs are still poorly understood. In this study we evaluated the expression of AIF and PARP and their regulatory microRNAs (miR-145, miR-210 and miR486) in the corpus cavernosum of rats subjected to semivoluntary alcoholism, but we failed to find any significant alteration.

MicroRNAs are abundant structures related to various physiological functions of cellular processes. In addition, they are involved in many pathophysiological processes, such as ED (Luo et al., 2013). Mullany et al. (2017) found that long-term alcohol consumption altered the expression of 84 microRNAs in normal rectal mucosal tissue. These results support the hypothesis that excessive alcohol consumption may influence the expression of microRNAs.

MicroRNA 145 is one of the most abundant microRNAs in the vascular wall and vascular smooth muscle cells, and is one of the most important communicating molecules responsible for regulating phenotypic modulation and vascular homeostasis. Its expression and function in muscle cells of the corpus cavernosum are still poorly understood. This microRNA is known to be pro apoptotic, also participating in cell differentiation. At physiological levels microRNA-145 also regulates the apoptotic mechanisms, differentiation and phenotypic modulation of smooth muscle cells of the corpus cavernosum and their vascular epithelium, corroborating with ED since increasing apoptotic rate impairs tissue homeostasis (Luo et al., 2017).

In this study, although we did not observe any significant alteration, the microRNA 145 expression in the alcoholic group was slightly increased. It could indicate an increase in apoptosis in the corpus cavernosum of alcoholic rats, which is one of the consequences of the alcohol consumption. Accordingly, Luo et al. (2013) observed an overexpression of microRNA-145 in gastric tissues after exposure to high doses of ethanol. On the other hand, the expression of microRNA 145 in smooth muscle tissue of the corpus cavernosum of diabetic and ED rats was significantly reduced when compared to the control group (Wei et al., 2011). In addition, the transplantation of bone marrowderived mesenchymal stem cells (BMSCs) overexpressing microRNA-145 attenuate age-related ED in rats (Liu et al.,
2019). Thus, these data suggests that miRNA-145 plays a crucial role on penile erection function.

MicroRNA-210, also a target of this study, was related to several cellular functions, such as hypoxia, angiogenesis, apoptosis, proliferation, differentiation, cell cycle regulation, DNA damage repair, mitochondrial metabolism and tumor growth. When overexpressed, it may inhibit AIF protein translocation from mitochondria to the nucleus, thereby preventing the induction of cell death (Wang et al., 2015). In this study, it is possible to observe a slight decrease in microRNA-210 expression in the alcoholic group. Although without statistical validation, its tendency to anti-apoptotic action can be observed.

MicroRNA-486 plays a role in myogenesis and cell plasticity and inhibits the mitochondrial-mediated apoptotic pathway (Li et al., 2018). Myogenesis is impaired by alcohol abuse and interferes with the nutritional status of the individual, impairing the balance between anabolic and catabolic mechanisms. It is associated with a $50 \%$ incidence of skeletal muscle myopathy resulting from decreased muscle protein synthesis and accelerated muscle proteolysis, causing lower micronutrient availability and consequently modulation of circulating and tissue growth factors (Molina et al., 2014). Chacon-Cabrera et al. (2017) found decreased levels of miR-486 and PARP protein expression in muscle of cachectic rats, evidencing the role of this microRNA in myogenesis. Nevertheless, we did not observed significant difference in this miR-486 expression from alcoholic animals compared to control.

Regarding immunohistochemistry analysis, we did not find significant difference when comparing control and alcoholic animals. Thus, we can suggest that different experimental models may influence the expression of microRNAs and AIF and PARP protein.

Sexual function is an association of psychological, endocrine, vascular and neurological situations. Thus, any of these factors may contribute to the occurrence of the ED (Shamloul \& Ghanem, 2013). At the end of this paper, we understand that there are at least two important ways to emphasize studies on human alcoholism and its relationship with sexual dysfunction: the search for genetic markers and the search for effective therapies for the treatment of this disease (Quintanilla et al., 2006).

In conclusion, our data showed that in the model of semivoluntary alcoholism there were no significant alterations in the expression of AIF and PARP and their regulatory microRNAs involved in apoptotic process (miR-145, miR210 and miR-486) in the corpus cavernosum of rats. 
SARRAIPO, V. S.; NETO, F. S. L.; CARVALHO, C. A. M.; SILVA, J. P.; DURAND, M. T.; SCHIMMING, B. C.; MARTINEZ, M.; GALLI, M. F. T. S.; BUONO, F. O.; TIEZZI, M. F. B. M.; NOVAIS, P. C.; GULA, I. S.; THOMAZINI, J. A.; FAZAN, V. P. S.; RODRIGUES, A. R.; TIRAPELLI, D. P. C.; CIRINO, M. L. A.; MOLINA, C. A. F.; JUNIOR, S. T. \& TIRAPELLI, L. F. Expression of AIF, PARP, and miRNAs MIR-145, MIR-210, and MIR-486 associated with apoptosis in the corpus cavernosum of rats subjected to chronic alcoholism model. Int. J. Morphol., 38(6):1639-1644, 2020.

SARRAIPO, V. S.; NETO, F. S. L.; CARVALHO, C. A. M.; SILVA, J. P.; DURAND, M. T.; SCHIMMING, B. C.; MARTINEZ, M.; GALLI, M. F. T. S.; BUONO, F. O.; TIEZZI, M. F. B. M.; NOVAIS, P. C.; GULA, I. S.; THOMAZINI, J. A.; FAZAN, V. P. S.; RODRIGUES, A. R.; TIRAPELLI, D. P. C.; CIRINO, M. L. A.; MOLINA, C. A. F.; JUNIOR, S. T. \& TIRAPELLI, L. F. Expresión de AIF, PARP y miRNAs MIR-145, MIR-210 y MIR-486 asociados con apoptosis en el cuerpo cavernoso de ratas sometidas a modelo de alcoholismo crónico. Int. J. Morphol., 38(6):1639-1644, 2020.

RESUMEN: Estudios previos de nuestro grupo describieron las consecuencias del uso de etanol en la erección del pene. Sin embargo, los mecanismos moleculares que rodean a los microARN, el proceso de apoptosis y su relación con la disfunción eréctil asociada con el consumo de alcohol aún no se conocen bien. El objetivo de este análisis fue evaluar el mecanismo de apoptosis mediante la expresión de AIF y PARP, así como sus microARN reguladores: miR-145, miR-210 y miR-486, en el cuerpo cavernoso de ratas sometidas a un modelo de alcoholismo semivoluntario. Se dividieron 24 ratas Wistar en dos grupos: control (C) grupo de ratas tratadas con etanol al $20 \%$ (A) durante siete semanas. Las muestras del cuerpo cavernoso se prepararon para el análisis inmunohistoquímico de la expresión de la proteína AIF y PARP, y la expresión del gen microRNAs miR-145, miR-210, miR-486 en tejido cavernoso se realizó por PCR en tiempo real. El análisis inmunohistoquímico mostró escaso etiquetado nuclear positivo para la proteína PARP y AIF en el cuerpo cavernoso de los animales de control y tratados con etanol. Después del análisis de la expresión de microARN miR-145, -210 y -486 no se encontraron resultados con diferencias estadísticas significativas entre los grupos control y alcoholizados. La expresión de AIF y PARP y sus microARN reguladores involucrados en el proceso apoptótico (miR-145, miR-210 y miR-486) no se alteraron en el cuerpo cavernoso de las ratas sometidas a alcoholismo semivoluntario.

PALABRAS CLAVE: Alcoholismo; Apoptosis; Disfunción eréctil; MicroRNAs.

\section{REFERENCES}

Burgos-Aceves, M. A.; Cohen, A.; Paolella, G.; Lepretti, M.; Smith, Y.; Faggio, C. \& Lionetti, L. Modulation of mitochondrial functions by xenobiotic-induced microRNA: From environmental sentinel organisms to mammals. Sci. Total Environ., 645:79-88, 2018.

Chacon-Cabrera, A.; Mateu-Jimenez, M.; Langohr, K.; Fermoselle, C.; GarcíaArumí, E.; Andreu, A. L.; Yelamos, J. \& Barreiro, E. Role of PARP activity in lung cancer-induced cachexia: Effects on muscle oxidative stress, proteolysis, anabolic markers, and phenotype. J. Cell Physiol., 232(12):3744-61, 2017.

Cheng, J. Y. W.; Ng, E. M. L.; Chen, R. Y. L. \& Ko, J. S. N. Alcohol consumption and erectile dysfunction: meta-analysis of population-based studies. Int. J. Impot. Res., 19(4):343-52, 2007.

da Cunha, J. P.; Lizarte Neto, F. S.; Novais, P. C.; Gattas, D.; de Carvalho, C. A. M.; Tirapelli, D. P. C.; Molina, C. A. F.; Tirapelli, L. F. \& Tucci Junior, S. Expression profiles of eNOS, iNOS and microRNA-27b in the corpus cavernosum of rats submitted to chronic alcoholism and Diabetes mellitus. Acta Cir. Bras., 32(1):38-45, 2017.

Drake, R. L.; Vogl, A. W. \& Mitchel, A. W. M. Gray's. Anatomia Clínica para Estudantes. 3rd ed. Rio de Janeiro, Elsevier, 2015.

Glina, S.; Cohen, D. J. \& Vieira, M. Diagnosis of erectile dysfunction. Curr. Opin. Psychiatry, 27(6):394-9, 2014.

Gonçalves, F. Z.; Lizarte Neto, F. S.; Novais, P. C.; Gattas, D.; Lourenço, L. G. \& de Carvalho, C. A. M. Expression profile of endothelin receptors (ETA and ETB) and microRNAs-155 and -199 in the corpus cavernosum of rats submitted to chronic alcoholism and diabetes mellitus. Braz. J. Med. Biol. Res., 51(3):e6329, 2018
Kulshreshtha, R.; Ferracin, M.; Negrini, M.; Calin, G. A.; Davuluri, R. V. \& Ivan, M. Regulation of microRNA expression: the hypoxic component. Cell Cycle, 6(12):1426-31, 2007.

Li, J.; Zhou, Q.; Yang, T.; Li, Y.; Zhang, Y.; Wang, J. \& Jiao, Z. SGK1 inhibits PM2.5-induced apoptosis and oxidative stress in human lung alveolar epithelial A549 cells. Biochem. Biophys. Res. Commun., 496(4):1291-5, 2018.

Liu, Q.; Cui, Y.; Lin, H.; Hu, D.; Qi, T.; Wang, B.; Huang, Z.; Chen, J.; Li, K. \& Xiao, H. MicroRNA-145 engineered bone marrow-derived mesenchymal stem cells alleviated erectile dysfunction in aged rats. Stem Cell Res. Ther, 10(1):398, 2019.

Lizarte, F. S.; Claudino, M. A.; Tirapelli, C. R.; Morgueti, M.; Tirapelli, D. P. C.; Batalhão, M. E.; Carnio, E. C.; Queiroz, R. H.; Evora, P. R. B.; Tucci Jr., S.; et al. Chronic ethanol consumption induces cavernosal smooth muscle dysfunction in rats. Urology, 74(6):1250-6. 2009.

Lizarte, F. S.; Morgueti, M.; Tirapelli, C. R.; Claudino, M. A.; Evora, P. R. B.; Novais, P. C.; Tirapelli, D. P. C.; Celotto, A. C.; Capellini, V. K.; Celini, F. P. M.; et al. Chronic alcoholism associated with diabetes impairs erectile function in rats. B. J. U. Int., 105(11):1592-7, 2010.

Luo, J.; Liu, L.; Wu, Z.; Chen, G.; Li, E.; Luo, L.; Li, F.; Zhao, S.; Wei, A. \& Zhao, $Z$. The effects of miRNA-145 on the phenotypic modulation of rat corpus cavernosum smooth muscle cells. Int. J. Impot. Res., 29(6):229-34, 2017.

Luo, X. J.; Liu, B.; Dai, Z.; Li, T. B.; Li, N. S.; Zhang, X. J.; Yang, Z. C.; Li, Y. J. \& Peng, J. Expression of apoptosis-associated microRNAs in ethanol-induced acute gastric mucosal injury via JNK pathway. Alcohol, 47(6):481-93, 2013.

Molina, P. E.; Gardner, J. D.; Souza-Smith, F. M. \& Whitaker, A. M. Alcohol abuse: critical pathophysiological processes and contribution to disease burden. Physiology (Bethesda), 29(3):203-15, 2014.

Mullany, L. E.; Herrick, J. S.; Wolff, R. K.; Stevens, J. R. \& Slattery, M. L. Alterations in microRNA expression associated with alcohol consumption in rectal cancer subjects. Cancer Causes Control, 28(6):545-55, 2017.

O'Keefe, J. H.; Bhatti, S. K.; Bajwa, A.; DiNicolantonio, J. J. \& Lavie, C. J. Alcohol and cardiovascular health: the dose makes the poison...or the remedy. Mayo Clin. Proc., 89(3):382-93, 2014.

Quintanilla, M. E.; Israel, Y.; Sapag, A. \& Tampier, L. The UChA and UChB ra lines: metabolic and genetic differences influencing ethanol intake. Addict. Biol., 11(3-4):310-23, 2006

Shamloul, R. \& Ghanem, H. Erectile dysfunction. Lancet, 381(9861):153-65, 2013.

Waltereit, R. \& Weller, M. The role of caspases 9 and 9-short (9S) in death ligandand drug-induced apoptosis in human astrocytoma cells. Mol. Brain Res., 106(1-2):42-9, 2002.

Wang, X. J.; Xu, T. Y.; Xia, L. L.; Zhong, S.; Zhang, X. H.; Zhu, Z. W.; Chen, D. R.; Liu, Y.; Fan, Y.; Xu, C.; et al. Castration impairs erectile organ structure and function by inhibiting autophagy and promoting apoptosis of corpus cavernosum smooth muscle cells in rats. Int. Urol. Nephrol., 47(7):1105-15, 2015.

Wei, A. Y.; Yang, Y.; He, S. H.; Luo, X. G.; Zhang, T. \& Liu, Y. Role of miR-145 in erectile dysfunction in diabetic rats. Nan Fang Yi Ke Da Хue Xue Bao, 31(6):1051-4, 2011

Corresponding author:

Luis Fernando Tirapelli

Ribeirão Preto Medical School

University of São Paulo

3900 Bandeirantes Avenue

Zip Code: 14049-900

Ribeirão Preto SP

BRASIL

Email: lab.biomol.cirurgia@fmrp.usp.br

Received: 08-05-2020

Accepted: 05-07-2020 